Fakultas Hukum Universitas Lancang Kuning, Jalan Yos Sudarso KM 8 Rumbai Pekanbaru, Riau,

Kode Pos 28266. Telp: (+62761)-51877

E-mail: jurnal.respublica@ac.id

Website: https://journal.unilak.ac.id/index.php/Respublica

Pelaksanaan Penempatan Tenaga Kerja Tempatan Sesuai Peraturan Daerah

Kabupaten Kampar Nomor 5 Tahun 2009 tentang Penempatan Tenaga Kerja pada

PT. Flora Wahana Tirta

\title{
Rino Rinaldo
}

Perhimpunan Advokat Indonesia , Pekanbaru, Email: rinorinaldo16@gmail.com

\section{Article Info}

Article History:

Received : 12-02-2020

Revised : 25-03-2020

Accepted : 15-05-2020

Published : 28-05-2020

Keywords:

Placement

Labor

Local

\begin{abstract}
The purpose of this study is to explain the position of the Board of Employment Development has a broad scope and is cross-sectoral in nature,then Manpower Development is an overall effort in all sectors and regions aimed at expanding employment opportunities. In the framework of implementing Presidential Decree No. 4 of 1980 concerning mandatory reporting of job vacancies, efforts should be made to the maximum extent possible to fill vacancies available by local (local) workers. The problem discussed in this study is the Implementation of Placement of Workers in accordance with the Local Regulations Kampar Regency Number 5 of 2009 concerning the Placement of Workers at PT. Flora Wahana Tirta.This type of research is Sociological legal research which is more directed at research that addresses the enactment of positive law, the enactment of positive law on people's lives and also the influence of non-legal factors on the formation of positive legal provisions.Muhammad Hasnan Husainu conducted a study of this research, with the research title Implementation of the Regional Regulation Policy of Kampar Regency No. 5 of 2009 concerning the Placement of Local Workers (Case Study of PT. Ramajaya Pramukti).Differences in studies conducted by Muhammad Hasnan Husainu are in the research location.Location of research conducted by Muhammad Hasnan Husainu at PT. Ramajaya Pramukti, while the research location in this article is PT. Flora Wahana Tirta.
\end{abstract}

\begin{abstract}
Abstrak
$\overline{\text { Pembangunan Ketenagakerjaan memiliki ruang lingkup yang luas }}$ dan bersifat lintas sektoral, maka Pembangunan Ketenagakerjaan adalah merupakan suatu upaya yang bersifat menyeluruh disemua sektor dan daerah yang ditujukan pada perluasan kesempatan kerja. Dalam rangka pelaksanaan Keputusan Presiden Nomor 4 Tahun 1980 tentang wajib lapor lowongan pekerjaan, diusahakan semaksimal mungkin pengisian lowongan kerja yang tersedia oleh tenaga kerja setempat (Lokal). Permasalahan yang di bahas dalam penelitian ini adalah bagaimana Pelaksanaan Penempatan Tenaga Kerja Tempatan Sesuai Peraturan Daerah Kabupaten Kampar Nomor 5 Tahun 2009 Tentang Penempatan Tenaga Kerja Pada PT. Flora Wahana Tirta. Jenis penelitian ini adalah penelitian hukum Sosiologis yang mana lebih diarahkan pada suatu penelitian yang membahas berlakunya hukum positif, berlakunya hukum positif terhadap kehidupan masyarakat dan juga pengaruh faktor-faktor
\end{abstract}


non hukum terhadap terbentuknya ketentuan-ketentuan hukum positif. Terhadap kajian mengenai penelitian ini, pernah dilakukan oleh Muhammad Hasnan Husainu, dengan judul penelitian Implementasi Kebijakan Peraturan Daerah Kabupaten Kampar No 5 Tahun 2009 Tentang Penempatan Tenaga Kerja Lokal (Studi Kasus PT. Ramajaya Pramukti). Perbedaan kajian yang dilakukan oleh Muhammad Hasnan Husainu terdapat pada lokasi penelitian. Lokasi penelitian yang dilakukan oleh Muhammad Hasnan Husainu pada PT. Ramajaya Pramukti, sementara lokasi penelitian pada artikel ini adalah PT. Flora Wahana Tirta.

\section{PENDAHULUAN}

Pembangunan ketenagakerjaan sebagai bagian integral dari pembangunan nasional berdasarkan Pancasila dan Undang-undang Dasar Negara Republik Indonesia Tahun 1945, dilaksanakan dalam rangka pembangunan manusia Indonesia seutuhnya dan pembangunan masyarakat Indonesia seluruhnya untuk meningkatkan harkat, martabat, dan harga diri tenaga kerja serta mewujudkan masyarakat sejahtera, adil, makmur, dan merata, baik materiil maupun spiritual. ${ }^{1}$ Pembangunan Ketenagakerjaan memiliki ruang lingkup yang luas dan bersifat lintas sektoral, maka Pembangunan Ketenagakerjaan adalah merupakan suatu upaya yang bersifat menyeluruh disemua sektor dan daerah yang ditujukan pada perluasan kesempatan kerja, meningkatkan mutu dan kemampuan serta Perlindungan Tenaga Kerja.

Laju pertumbuhan angkatan kerja yang tinggi membawa akibat yang sangat berat pada penyediaan kesempatan kerja. ${ }^{2}$ Maka untuk meningkatkan kesejahteraan rakyat khususnya Tenaga Kerja melalui pembangunan ekonomi berbasis kerayaktan serta pembinaan dan pembangunan sumber daya manusia menjadi titik perhatian, dimana masyarakat tidak hanya sebagai objek tetapi juga sebagai subjek dalam penyelenggara pembangunan.

Berdasarkan pasal 2 Undang-Undang Nomor 13 Tahun 2003 dinyatakan bahwa : pembangunan ketenagakerjaan berlandasan Pancasila dan Undang-Undang Dasar Negara Republik Indonesia Tahun 1945. Selanjutnya, dalam penjelasan pasal tersebut ditegaskan bahwa: pembangunan ketenagakerjaan dilaksanakan dalam rangka pembangunan manusia Indonesia seutuhnya. Oleh sebab itu pembangunan ketenagakerjaan dilaksanakan untuk mewujudkan manusia dan masyarakat Indonesia yang sejahtera, adil, makmur dan merata, baik materil maupun spiritual. ${ }^{3}$ Perluasan lapangan kerja dan pemerataan kesempatan kerja, dimaksudkan agar sebagian besar angkatan kerja dapat ditampung dalam lapangan kerja

\footnotetext{
1 Nevey Varida Ariani,Penegakan Hukum Terhadap Tenaga Kerja Asing Ilegal Di Indonesia, Jurnal Penelitian Hukum De Jure 18, no. 1, (Maret 2018) 116.

2 Haryo Kuncoro, “Dimensikualitatif Keberhasilan Perluasan Kesempatan Kerja”, Jurnal Ekonomi dan Bisnis Indonesia 14, no. 1, (1999), 22.

3 Abdul Khakim, Dasar-dasar hukum ketenagakerjaan indonesia,Cetakan I,(Kalbar: PT Citra Aditya Bakti,2009),hlm,7-9
} 
yang Produktif dan Remunerative. Selain itu juga diarahkan untuk dapat mempercepat pergeseran strukur lapangan kerja dari sektor pertanian ke sektor industri. ${ }^{4}$

Pada awalnya hubungan kerja antara pengusaha dan pekerja/buruh hanya menyangkut kepentingan perdata, yang dalam hal ini berarti terkait dengan aspek hukum perdata. Oleh sebab itu pembangunan ketenaga kerjaan dilaksanakan untuk mewujudkan manusia dan masyarakat Indonesia yang sejahtera, adil, makmur dan merata, baik materil maupun spiritual. ${ }^{5}$

Hukum ketenagakerjaan dahulu disebut hukum perburuhan yang merupakan terjemahan dari arbeidsrechts.Terdapat beberapa pendapat atau batasan tentang pengertian hukum perburuan. Molenaar memberikan batasan pengertian dari arbeidsrechts adalah bagian dari hukum yang berlaku yang pada pokoknya mengatur hubungan antara buruh dengan majikan, antara buruh dengan buruh dan antara buruh dengan penguasa.

Pasal 1 angka 1 Undang-undang Nomor 13 Tahun 2003 tentang Ketenagakerjaan menyebutkan bahwa ketenagakerjaan adalah segala hal yang berhubungan dengan tenaga kerja pada waktu sebelum, selama, dan sesudah masa kerja. Dari pengertian ketenagakerjaan tersebut, dapat ditarik rumusan pengertian hukum ketenagakerjaan yaitu semua peraturan hukum yang berkaitan dengan tenaga kerja baik sebelum bekerja (pra employment) antara lain menyangkut pemagangan, kewajiban mengumumkan lowongan kerj, dan lain-lain. ${ }^{6}$

Sesuai dengan peranan dan kedudukan tenaga kerja, diperlukan pembangunan ketenagakerjaan untuk meningkatkan kualitas tenaga kerja dan peran sertanya dalam pembangunan serta peningkatan perlindungan tenaga kerja dan keluarganya sesuai dengan harkat dan martabat kemanusiaan.Untuk itulah sangat diperlukan adanya perlindungan terhadap tenaga kerja dimaksudkan untuk menjamin hak-hak dasar pekerja/ buruh dan menjamin kesamaan kesempatan serta perlakuan tanpa diskriminasi atas dasar apapun untuk mewujudkan kesejahteraan pekerjha/buruh dan keluarganya dengan tetap memperhatiakan perkembangan kemajuan dunia usaha.

Dalam rangka pelaksanaan Keputusan Presiden Nomor 4 Tahun 1980 tentang wajib lapor lowongan pekerjaan, diusahakan semaksimal mungkin pengisian lowongan kerja yang tersedia oleh tenaga kerja setempat (Lokal). Apabila tenaga setempat tidak bisa mengisi lowongan tersebut dikarenakan berbagai hal maka diusahakan pengisiannya melalui mekanisme antar kerja antar daerah (AKAD). Penyebaran tenaga kerja yang merata dalam rangka pelaksanaan pembangunan di daerah-daerah yang potensial

\footnotetext{
${ }^{4}$ Sri Warjiati, hukum ketenagakerjaan keselamatan keselamatan kerja dan perlindungan upah pekerja wanita,Cetakan I,(Bandung: Tarsito,1998), hlm,1

${ }^{5}$ Abdul Khakim, Dasar-dasar hukum ketenagakerjaan indonesia,Cetakan I,(Kalbar: PT Citra Aditya Bakti,2009),hlm,7-9

${ }^{6}$ Indra Afrita, Hukum Ketenagakerjaan dan penyelesaian sengketa hubungan industrial di indonesia,Cetakan I,(Yogyakarta: Absolute Media,2015),hlm,9.
} 
dengan sumber daya alam akan tetapi kekurangan dalam sumber daya manusia. Setiap penempatan tenaga kerja di dalam negeri harus dilaksanakan dengan Surat Persetujuan Penempatan (SPP) yang bisa didapatkan oleh pelaksana penempatan dengan menunjukan bukti adanya penempatan dari pengguna jasa dengan penjelasan ruang lingkup sasaran penempatannya, baik lokal maupun daerah. ${ }^{7}$

Perluasan lapangan kerja dan pemerataan kesempatan kerja, dimaksudkan agar sebagian besar angkatan kerja dapat ditampung dalam lapangan kerja yang produktif dan remunerative. Selain itu juga diarahkan untuk dapat mempercepat pergeseran strukur lapangan kerja dari sektor pertanian ke sektor industry. ${ }^{8}$ Hal ini disebabkan telah terjadinya ketidakseimbangan antara lapangan pekerjaan dan pencari kerja. Ketidakseimbangan antara pertumbuhan angkatan kerja dan penciptaan lapangankerja akan menyebabkan tingginya angka pengangguran, Terutama bagi tenaga kerja lokal.

Seharusnya tenaga kerja lokal atau warga setempat itu yang lebih dulu diberi kesempatan untuk bekerja disebuah perusahan, yang ada di daerah masing-masing, bukan mendahulukan pekerja asing. Selain itu juga banyak terjadi permasalahan bagi tenaga kerja lokal yang diterima oleh perusahaan tersebut, dimana banyak perusahaan menggunakan sistem outsourcing.

Berdasarkan hukum Ketenagakerjaan, istilah Outsourcing sebenarnya bersumber dari ketentuan yang terdapat dalam pasal 64 Undang-Undang Nomor 13 tahun 2003 tentang ketenagakerjaan, yang menyatakan bahwa perusaaan dapat menyerahkan sebagaian pelaksanaan pekerjaan kepad perusahaan lainnya melalui perjanjian pemborongan pekerjaan atau penyediaan jasa pekerja yang dibuat secara tertulis. ${ }^{9}$

Permasalahan yang akan di bahas dalam penelitian ini adalah bagaimana Pelaksanaan Penempatan Tenaga Kerja Tempatan Sesuai Peraturan Daerah Kabupaten Kampar Nomor 5 Tahun 2009 Tentang Penempatan Tenaga Kerja Pada PT. Flora Wahana Tirta. Jenis penelitian ini adalah penelitian hukum Sosiologis yang mana lebih diarahkan pada suatu penelitian yang membahas berlakunya hukum positif, berlakunya hukum positif terhadap kehidupan masyarakat dan juga pengaruh faktor-faktor non hukum terhadap terbentuknya ketentuan-ketentuan hukum positif. ${ }^{10}$

Penelitian ini merupakan penelitian Kualitatif yang bertujuan untuk mengetahui Pelaksanaan Penempatan Tenaga Kerja Tempatan Sesuai Peraturan Daerah Kabupaten Kampar Nomor 5 Tahun 2009 Tentang Penempatan Tenaga Kerja Pada PT. Flora Wahana Tirta. Analisis data dalam menarik suatu kesimpulan dalam penelitian ini menggunakan

\footnotetext{
${ }^{7}$ Lalu Husni, Pengantar Hukum Ketenagakerjaan,Cetakan XIII, (Jakarta: PT.RajaGrafindo Persada, 2015), hlm, 88-89.

${ }^{8}$ Sri Warjiati, hukum ketenagakerjaan keselamatan keselamatan kerja dan perlindungan upah pekerja wanita,Cetakan I,(Bandung: Tarsito,1998), hlm,1

9 Andrian Sutedi, hukum perburuhan,Cetakan II,(Jakarta: Sinar Grafika,2011),hlm,27

${ }^{10}$ Pedoman penulisan skripsi, FH Universitas Lancang Kuning Pekanbaru, 2012.
} 
metode berfikir Dedukatif yaitu cara berfikir yang menarik suatu kesimpulan dari suatu pernyataan atau dalil yang bersifat umum menjadi suatu pernyataan atau kasus yang bersifat khusus.

Terhadap kajian mengenai penelitian ini, pernah dilakukan oleh Muhammad Hasnan Husainu, ${ }^{11}$ dengan judul penelitian Implementasi Kebijakan Peraturan Daerah Kabupaten Kampar No 5 Tahun 2009 Tentang Penempatan Tenaga Kerja Lokal (Studi Kasus PT. Ramajaya Pramukti). Perbedaan kajian yang dilakukan oleh Muhammad Hasnan Husainu terdapat pada lokasi penelitian. Lokasi penelitian yang dilakukan oleh Muhammad Hasnan Husainu pada PT. Ramajaya Pramukti, sementara lokasi penelitian pada artikel ini adalah PT. Flora Wahana Tirta.

\section{ANALISIS DAN PEMBAHASAN}

\section{Pelaksanaan Penempatan Tenaga Kerja Tempatan Sesuai Peraturan Daerah Kabupaten Kampar Nomor 5 Tahun 2009 Tentang Penempatan Tenaga Kerja Pada PT.Flora Wahana Tirta}

Pembangunan Kabupaten Kampar adalah semua kegiatan untuk tercapainya pembaharuan kearah yang lebih baik, dan untuk menciptakan masyarakat adil dan makmur. Pada hakekatnya pembangunan Kabupaten Kampar merupakan pembangunan manusia seutuhnya dan pembangunan masyarakat Kampar seluruhnya. Laju pertumbuhan penduduk Kabupaten Kampar yang tinggi mengakibatkan jumlah angkatan kerja setiap tahunnya semakin meningkat sedangkan kesempatan kerja yang tersedia belum dapat memenuhi kebutuhan kerja yang tersedia sesuai dengan jumlah pencari kerja yang ada. Dalam mewujudkan pembangunan ketenagakerjaan, pemerintah diharapkan dapat menyusun dan menetapkan perencanaan tenaga kerja. Di mana, perencanaan tenaga kerja dimaksudkan agar dapat dijadikan dasar dan acuan dalam penyusunan kebijakan, strategi, implementasi (pelaksanaan), dan program pembangunan ketenagakerjaan. ${ }^{12}$

Tenaga kerja merupakan salah satu ujung tombak sebagai unsur penunjang yang mempunyai peran yang sangat penting bagi keberhasilan pembangunan, sehingga kebijakan dibidang ketenagakerjaan dalam program pembangunan selalu diusahakan pada terciptanya kesempatan kerja sebanyak mungkin diberbagai bidang usaha yang diimbangi dengan peningkatan mutu dan peningkatan perlindungan terhadap tenaga kerja. Hal ini berlaku pada semua bidang kerja dan bersifat menyeluruh pada semua sektor.

Tenaga kerja adalah tulang punggung dalam peningkatan pembangunan pada umumnya, pertumbuhan industri pada khususnya. Oleh karenanya seluruh kegiatan yang

11 Muhammad Hasnan Husainu, Implementasi Kebijakan Peraturan Daerah Kabupaten Kampar No 5 Tahun 2009 Tentang Penempatan Tenaga Kerja Lokal (Studi Kasus Pt. Ramajaya Pramukti), Jurnal Online Mahasiswa Fakultas Ilmu Sosial dan Politik Universitas Riau, Volume 1 Nomor 2. Oktober 2014.

12 Ibid. Hlm. 2 
yang dilakukan tenaga kerja akan mengandung aspek hubungan sosial, hubungan hukum dan hubungan antar/intern organisasi yang dapat menimbulkan hak dan kewajiban dan dilaksanakan berdasarkan nilai-nilai yang terkandung dalam Pancasila.

Dalam prinsip otonomi daerah yang dituangkan dalam Konstitusi Negara Republik Indonesia, dijelaskan bahwa pemerintah daerah diberikan kewenangan untuk mengatur dan mengurus pemerintahan seluas-luasnya kecuali yang diatur lain dalam undangundang. ${ }^{13}$ harapan dengan adanya otonomi daerah, bisa memperoleh kesejahteraan dalam bidang kesempatan kerja yang lebih baik dan meningkat. Tentunya, hal tersebut harus didukung oleh peran pemerintah daerah dalam memperjuangkan hak masyarakat melalui penggunaan kewenangan daerah otonom secara tepat dan bijaksana. ${ }^{14}$ Peraturan daerah dapat berfungsi sebagai alat untuk memperlancar jalannya pemerintah di daerah dan juga dapat memberi petunjuk terhadap hal-hal yang telah diatur dan dilaksanakan. Undang-Undang nomor 13 Tahun 2003 tentang ketenagakerjaan pada Pasal 7 di jelaskan bahwa dalam rangka pembangunan ketenagakerjaan, pemerintah menetapkan kebijakan dan menyusun perencanaan tenaga kerja.

Daerah Kabupaten Kampar mengalami peningkatan jumlah pencari kerja. Para pencari kerja lokal maupun non-lokal berusaha bersaing dalam mendapatkan pekerjaan. Dalam memperjuangkan pekerjaan, setiap orang memiliki kesempatan yang sama dan tanpa diskriminasi dalam memperoleh pekerjaan. Peran pemerintah daerah sangat penting dalam membuat suatu kebijakan guna melindungi masyarakat lokal dalam memperoleh pekerjaan tanpa bertentangan dengan prinsip demokrasi. Pemerintah daerah Kabupaten Kampar menerbitkan Peraturan Daerah Nomor 5 Tahun 2009 tentang Penempatan Tenaga Kerja sebagai bentuk kebijakan dalam melindungi masyarakat lokal.

Berdasarkan Perda Nomor 5 Tahun 2009 Kabupaten Kampar yang dimaksud tenaga kerja lokal adalah tenaga kerja yang lahir di Kabupaten Kampar secara turun temurun dan dalam waktu tertentu tinggal di Kabupaten Kampar atau yang memiliki kartu keluarga atau KTP kabupaten Kampar. Tenaga kerja lokal yang menjadi prioritas ditempatkan di perusahaan adalah tenaga kerja yang telah terdaftar di dinas sosial dan tenaga kerja kabupaten Kampar dan telah memiliki kartu pencari kerja.

Kebijakan Pemerintah Daerah Kabupaten kampar untuk memberikan kesempatan bagi tenaga kerja lokal dapat dilihat pada Pasal 7 ayat (1)Peraturan Daerah Kabupaten Kampar nomor 5 tahun 2009 tentang penempatan tenaga kerja yang berbunyi: “Setiap perusahaan harus mempekerjakan 40\% (empat puluh persen) tenaga kerja lokal dan $60 \%$ (enam puluh persen) tenaga kerja non lokal, baik tenaga kerja yang terampil maupun

\footnotetext{
${ }^{13}$ Fuqoha, Perlindungan Hukum Terhadap Kesempatan Kerja Bagi Masayarakat Lokal Di Kota Cilegon, Jurnal Wawasan Yuridika, Volume 2, Nomor 2, September 2018, hlm 129.

${ }^{14}$ Ibid
} 
tidak terampil”. Dengan adanya peraturan daerah ini, diharapkan penduduk di Kabupaten Kampar bisa mendapatkan pekerjaan di perusahaan-perusahaan yang ada di Kabupaten Kampar dengan tujuan agar dapat mengurangi tingkat pengangguran, dan dapat meningkatkan kesejahteraan terutama penduduk tempatan.

Untuk melihat pelaksanaan penempatan tenaga kerja tempatan di kabupaten Kampar, berdasarkan Perda No. 5 Tahun 2009 tentang Penempatan Tenaga Kerja pada PT. Flora Wahana Tirta, maka disebar kuisioner kepada karyawan mengenai apakah penempatan tenaga kerja lokal terlaksana pada PT. Flora Wahana Tirta. Hasil kuisioner mengenai jawaban responden terhadap pelaksanaan penempatan tenaga kerja di PT Flora Wahana Tirta dapat dilihat pada tabel berikut:

Tabel 1: Jawaban Responden Mengenai Pelaksanaan Penempatan Tenaga Kerja Lokal

\begin{tabular}{|c|l|c|c|}
\hline No & \multicolumn{1}{|c|}{ Jawaban Responden } & Jumlah & Persentase (\%) \\
\hline 1 & Terlaksana & 1 & 11,11 \\
\hline 2 & Tidak Terlaksana & 9 & 88,89 \\
\hline \multicolumn{2}{|c|}{ Jumlah } & $\mathbf{1 0}$ & $\mathbf{1 0 0}$ \\
\hline
\end{tabular}

Sumber: Data Olahan, 2018

Berdasarkan tabel tersebut dapat diketahui bahwa hampir semua responden mengatakan bahwa penempatan tenaga kerja lokal tidak terlaksana pada PT Flora Wahana Tirta sesuai dengan jawaban responden sebanyak 9 atau 88,89\% responden memberikan jawaban penempatan tenaga kerja lokal tidak terlaksana, sebanyak 1 atau 11,11\% responden mengatakan tenaga kerja lokal terlaksana pada PT Flora Wahana Tirta.

Berdasarkan hasil wawancara dengan Humas PT Flora Wahana Tirta menyatakan bahwa mengenai tenaga kerja lokal perusahaan telah banyak menggunakan tenaga kerja lokal. berdasarkan KTP tenaga kerja yang bekerja di PT Flora wahana Tirta adalah masyarakat Kabupaten Kampar. ${ }^{15}$

Berdasarkan wawancara terhadap responden, diperoleh jawaban bahwa tenaga kerja lokal yang dimaksud didalam Perda Nomor 5 tahun 2009 tentang Tenaga kerja Tempatan bukanlah berdasarkan Kartu Tanda Penduduk saja, namun juga tenaga kerja yang lahir di Kabupaten Kampar secara turun temurun atau berdomisili dalam jangka waktu tertentu atau berdasarkan perkawinan campuran. Hal ini yang jarang diperhatikan oleh perusahaan yang ada di Kabupaten Kampar, sebelum melakukan penerimaan pegawai perusahaan mestinya melakukan pengecekan kepada tokoh masyarakat setempat mengenai tenaga kerja local sesuai yang tertuang dalam Perda tersebut, namun hal inilah

${ }^{15}$ Wawancara dengan Humas PT Flora Wahana Tirta Bapak Tondolan Harahap, Pada hari Rabu Tanggal 21 Februari 2018 bertempat di PT Flora Wahana Tirta 
yang hampir jarang dilakukan oleh perusahaan yang ada di Kabupaten Kampar. ${ }^{16}$

Tenaga kerja lokal merupakan salah satu sumber daya yang akan terkena dampak globalisasi ekonomi, dimana wilayah tidak lagi menjadi penghalang dan adanya kebebasan pertukaran barang, jasa, modal maupun tenaga kerja, sehingga Perlindungan Tenaga Kerja Lokal menjadi isu ketenagakerjaan yang cukup hangat diperbincangkan. Dampak globalisasi ekonomi terhadap tenaga kerja lokal, perlu dikelola agar tidak menimbulkan kecemburuan sosial dengan tenaga kerja pendatang.

\section{Hambatan Dalam Pelaksanaan Penempatan Tenaga Kerja Tempatan Sesuai Peraturan Daerah Kabupaten Kampar Nomor 5 Tahun 2009 Tentang Penempatan Tenaga Kerja Pada PT. Flora Wahana Tirta}

Masalah ketenagakerjaan pada dasarnya ada dua hal, yaitu masalah kesempatan kerja dan masalah kualitas tenaga kerja. Laju pertumbuhan penduduk Indonesia yang tinggi mengakibatkan jumlah angkatan kerja setiap tahunnya semakin meningkat, sedangkan kesempatan kerja yang tersedia belum dapat memenuhi kebutuhan kerja sesuai dengan jumlah pencari kerja yang ada. Hal ini mengakibatkan ketidakseimbangan antara besarnya jumlah penduduk yang membutuhkan pekerjaan dengan kesempatan kerja yang tersedia. $^{17}$

Di Kabupaten Kampar dalam kegiatan bisnis para pelakuusaha atau bisnis membuka dan menjalankan bisnis mereka dengan mengunakan berbagai bentuk-bentuk badan hukum salah satu bentuk badan hukum yang sangat dominan digunakan adalahbadan hukum Perseroan Terbatas yaitu PT Flora Wahana Tirta yang dalam pelaksanaannnya tidak menjalankan sepenuhnya ketentuan didalam Perda Nomor 5 tahun 2009 tentang Penempatan Tenaga Kerja di Kabupaten Kampar, terdapat beberapa hambatan dalam pelaksanaannya yaitu:

\section{Terbatasnya Sumber Daya Yang Berkualitas}

Tenaga kerja adalah Sumber Daya Manusia yang merupakan faktor yang teramat penting bagi terselenggaranya pembangunan nasional di Negara Republik Indonesia. ${ }^{18}$ Sumber daya adalah kemampuan yang dimiliki oleh organisasi baik SDM dalam menunjang pelaksanaan kebijakan maupun sarana dan prasarana untuk mendukung pelaksanaan kebijakan. Sumber daya merupakan salah satu faktor penting dalam implementasi

\footnotetext{
${ }^{16}$ Wawancara dengan Bapak Razi Kani, S.Sos selaku Kepala Bidang Penempatan dan Pelatihan Produktifitas Tenaga Kerja Dinas Sosial dan Tenaga Kerja Kabupaten Kampar, pada hari Senin Tanggal 12 Februari 2018 bertempat di Dinas Sosial dan Tenaga Kerja Kabupaten Kampar.

17 Gesang Sri Wulandari, Nabitatus Sa’adah, Perlindungan Hukum Tenaga Kerja Indonesia Atas Kebijakan Pemerintah Terkait Penerimaan Tenaga Kerja Asing Di Indonesia, Kanun Jurnal Ilmu Hukum, Volume 21, No. 2, Agustus 2019. hlm. 321.

18 Delia Amanda Iroth, AsPek Hukum Pengembangan Sumber Daya Manusia (Sdm) Menurut UndangUndang No. 13 Tahun 2003 Tentang Ketenagakerjaan, Jurnal Lex Crimen Volume 6, No. 2,Maret-April 2017, hlm. 128.
} 
kebijakan/program, karena bagaimanapun baiknya bijaksanaan atau program itu di rumuskan telah memenuhi kejelasan perintah dan konsistensi dalam menyampaikan perintah dan arahan informasi tanpa adanya dukungan sumber daya yang memadai maka kebijakan akan mengambil kesulitan dalam mengimplementasikannya.

Jika melihat kembali fenomena perusahaan tidak mau mempekerjakan tenaga kerja lokal dan lebih memilih tenaga kerja dari luar daerah, alasan tersebut karena tenaga kerja lokal tidak memiliki keahlian dan kemampuan dan juga tidak berkompeten dalam bidangnya, dan bila dilihat tenaga kerja dari luar daerah dapat memenuhi persyaratan perusahaan baik dari skill, dan komptensinnya dalam pekerjaan, sehingga penempatan tenaga kerja lokal masih mengalami kendala. ${ }^{19}$

Untuk tenaga kerja yang lulus seleksi pada PT. Flora Wahana Tirta tenaga kerja harus mempertimbangkan beberapa faktor yang mungkin sangat berpengaruh terhadap kelangsungan perusahaan. Manajer tenaga kerja harus bisa melihat karakteristik dan kualifikasi yang dimiliki para tenaga kerja yang akan ditempatkan dalam suatu tugas atau pekerjaan tertentu. Oleh karena itu, sebelum menempatkan tenaga kerja di tempat mereka harus bekerja, perlu dipertimbangkan beberapa faktor antara lain; keahlian, keterampilan, kualifikasi. ${ }^{20}$ Pentingnya kualitas Sumber Daya Manusia menjadi sangat diperlukan pada masa sekarang mengingat persaingan antar tenaga kerja secara global yang semakin ketat. Unit Pelaksana Teknis Balai Latihan Kerja sebagai Lembaga Pelatihan Milik Pemerintah dalam menghadapi tantangan saat ini dan kedepan adalah dengan meningkatkan daya saing tenaga kerja ${ }^{21}$.

\section{Keterbatasan Informasi Kerja Bagi Pencari Kerja}

Keterbatan informasi pekerjaan menjadi kendala dan hambatan dalam tenaga kerja lokal mendapatkan pekerjaan, pihak Dinas Sosial dan Tenaga Kerja Kabupaten Kampar telah berupaya agar tenaga kerja dapat di tempatkan pada perusahaan yang ada, mulai dari himbauan, sosialisasi, hingga mengadakan pertemuan dengan perusahaan yang ada di Kabupaten Kampar. ${ }^{22}$ Berdasarkan hasil kuisioner terhadap responden, 57\% menyatakan tidak memperoleh informasi mengenai lowongan pekerjaan pada PT Flora Wahana Tirta.

\footnotetext{
${ }^{19}$ Wawancara dengan Bapak Razi Kani, S.Sos selaku Kepala Bidang Penempatan dan Pelatihan Produktifitas Tenaga Kerja Dinas Sosial dan Tenaga Kerja Kabupaten Kampar, pada hari Senin Tanggal 12 Februari 2018 bertempat di Dinas Sosial dan Tenaga Kerja Kabupaten Kampar

${ }^{20}$ Wawancara dengan Humas PT Flora Wahana Tirta Bapak Tondolan Harahap, Pada hari Rabu Tanggal 21 Februari 2018 bertempat di PT Flora Wahana Tirta

${ }^{21}$ Delia Amanda Iroth, Op. Cit., hlm 131.

${ }^{22}$ Wawancara dengan Bapak Razi Kani, S.Sos selaku Kepala Bidang Penempatan dan Pelatihan Produktifitas Tenaga Kerja Dinas Sosial dan Tenaga Kerja Kabupaten Kampar, pada hari Senin Tanggal 12 Februari 2018 bertempat di Dinas Sosial dan Tenaga Kerja Kabupaten Kampar
} 
Pemberi kerja wajib menyampaikan informasi lowongan pekerjaan secara tertulis kepada Instansi yang bertanggung jawab dibidang ketenagakerjaan kabupaten/kota. Informasi lowongan pekerjaan memuat :

a. Jumlah Tenaga Kerja yang dibutuhkan;

b. Jenis pekerjaan, jabatan dan syarat-syarat jabatan yang digolongkan dalam jenis kelamin, usia, pendidikan, keterampilan, keahlian, pengalaman kerja dan syaratsyarat lain yang diperlukan;

c. Pengantar Kerja/petugas antar kerja mencatat Informasi lowongan pekerjaan ke dalam daftar isian permintaan tenaga kerja ( AK/ III) dan menerbitkan bukti lapor lowongan pekerjaan;

d. Informasi lowongan pekerjaan (AK/III) pemenuhannya diisi dari data pencari kerja yang terdaftar (AK/II);

e. Pencari kerja yang memenuhi persyaratan jabatan yang dibutuhkan dilakukan pemanggilan dengan menggunakan kartu antar kerja/kartu panggilan kepada pencari kerja (AK/IV);

f. Instansi yang bertanggung jawab dibidang ketenagakerjaan kab/kota mengirimkan calon tenaga kerja kepada pemberi kerja dengan menggunakan Kartu antar kerja/ Surat Pengantar calon tenaga kerja (AK/V);

g. Instansi yang bertanggung jawab dibidang ketenagakerjaan kab/kota bersamasama dengan pemberi kerja melakukan seleksi calon tenaga kerja sesuai dengan persyaratak jabatan yang dibutuhkan.

\section{Tidak Adanya Pelaporan Lowongan Perusahaan Ke Dinas Sosial dan Tenaga Kerja Kabupaten Kampar}

Sesuai dengan Perda Nomor 5 Tahun 2009 tentang Penempatan Tenaga Kerja Perusahaan diwajibkan untuk melaporkan lowongan kerja ke Dinas Sosial dan Tenaga kerja Kabupaten Kampar. Selain itu ketentuan didalam Pasal 2 ayat 1 Keputusan Presiden Republik Indonesia Nomor 4 tahun 1980, bahwa: “Setiap pengusaha atau pengurus wajib segera melaporkan secara tertulis setiap ada atau akan ada lowongan pekerjaan kepada Menteri atau pejabat yang ditunjuknya”. Namun dalam kenyataannya masih ada perusahaan yang di Kabupaten Kampar yang belum melaporkannya. ${ }^{23}$

Adapun bentuk laporannya memuat:

a. Jenis tenga kerja yang dibutuhkan.

b. Jenis pekerjaan dan syarat-syarat jabatan yang digolongan dalam jenis kelamin, usia, pendidikan, keterampilan/keahlian, pengalaman serta syarat-syarat lain yang dipandang perlu.

\footnotetext{
${ }^{23}$ Wawancara dengan Bapak Razi Kani, S.Sos selaku Kepala Bidang Penempatan dan Pelatihan Produktifitas Tenaga Kerja Dinas Sosial dan Tenaga Kerja Kabupaten Kampar, pada hari Senin Tanggal 12 Februari 2018 bertempat di Dinas Sosial dan Tenaga Kerja Kabupaten Kampar
} 
Perlunya wajib lapor lowongan pekerjaan ini dilakukan agar instansi yang bertanggung jawab dibidang ketenagakerjaan mengetahui lowongan pekerjaan yang tersedia di perusahaan tersebut sekaligus sebagai kontrol terhadap jumlah tenaga kerja yang dipekerjakan. Oleh sebab itu maka setiap perusahaan yang ada di Kabupaten Kampar wajib memberikan informasi mengenai lowongan pekerjaan kepada Dinas Sosial dan Tenaga Kerja Kabupaten Kampar, dan kemudian Dinas Sosial dan Tenaga Kerja Kabupaten Kampar dapat memberikan pengumuman baik melalui media massa ataupun media elektronik agar lowongan tersebut diketahui oleh masyarakat.

\section{Upaya Penyelesaian Terhadap Hambatan Pelaksanaan Penempatan Tenaga Kerja Tempatan Sesuai Peraturan Daerah Kabupaten Kampar Nomor 5 Tahun 2009 Tentang Penempatan Tenaga Kerja Pada PT. Flora Wahana Tirta}

\section{Meningkatkan Pelatihan Kerja}

Dinas Sosial dan Tenaga Kerja Kabupaten Kampar bahwa sebagai pihak yang mempunyai kewenangan dalam perlindungan tenaga kerja lokal di Kabupaten Kampar, maka dilakukan upaya-upaya berikut :

a. Peningkatan kompetensi Pencaker melalui pelatihan tenaga kerja berbasis kompetensi, dan pemagangan;

b. Pembinaan calon wirausaha baru melalui pelatihan kewirausahaan sesuai minat bakat pencaker, dalam rangka perluasan kesempatan kerja;

c. Melaksanakan Seminar dalam rangka merubah mindset dan meningkatkan kapasitas pencaker;

d. Optimalisasi koordinasi lintas sektoral melalui Lembaga Kerjasama Tripartit, Tim Deteksi Dini Ketenagakerjaan, dan Forum Koordinasi Jejaring Pemagangan;

e. Optimalisasi pembinaan hubungan industrial kepada pengusaha, pekerja, dan serikat pekerja/serikat buruh.

\section{Melaksanakan Job Fair}

Keterbatasan informasi bagi masyarakat local untuk mendapatkan pekerjaan salah satunya adalah karena kurangnya informasi mengenai lowongan pekerjaan. Dinas Sosial dan Tenaga Kerja Kabupaten Kampar dapat melakukan Job Fair sehingga masyarakat mengetahui adanya penerimaan tenaga kerja, khususnya tenaga kerja tempatan. ${ }^{24}$ Melalui job fair para pencari kerja dapat mengisi posisi lowongan pekerjaan yang ditawarkan dengan memilih langsung jenis pekerjaan sesuai dengan bakat, minat dan keahlian yang dimiliki.

\footnotetext{
${ }^{24}$ Wawancara dengan Bapak Razi Kani, S.Sos selaku Kepala Bidang Penempatan dan Pelatihan Produktifitas Tenaga Kerja Dinas Sosial dan Tenaga Kerja Kabupaten Kampar, pada hari Senin Tanggal 12 Februari 2018 bertempat di Dinas Sosial dan Tenaga Kerja Kabupaten Kampar
} 


\section{Melakukan Sosialisasi dan Penyuluhan Hukum}

Penyuluhan dan sosialisasi kepada masyarakat terutama para pencari kerja untuk mengikuti Program Pelatihan Kerja serta lowongan pekerjaan dilakukan dengan sosialisasi mengenai ketentuan tenaga kerja tempatan. Sosialisasi program ini dilakukan dalam rangka memberikan bekal pemahaman kepada calon peserta tentang kegiatan yang akan dilaksanakan. Media sosialisasi tersebut antara lain melalui media cetak. Cara sosialisasi dengan media ini ialah melalui leaflet dan banner yang diletakkan di papanpapan pengumuman Dinas Sosial dan Tenaga Kerja, Kabupaten Kampar, serta spanduk yang diletakkan di depan Kantor Dinas Sosial dan Tenaga kerja Kabupaten Kampar. ${ }^{25}$

\section{KESIMPULAN}

Pelaksanaan Penempatan Tenaga Kerja Tempatan Sesuai Peraturan Daerah Kabupaten Kampar Nomor 5 Tahun 2009 Tentang Penempatan Tenaga Kerja Pada PT. Flora Wahana Tirta tidak terlaksana dengan baik, ketentuan 40\% tenaga kerja lokal tidak dipenuhi oleh PT Flora Wahana Tirta. Dimana terdapat hambatan berupa terbatasnya sumber daya yang berkualitas, kurangnya informasi kerja bagi pencari kerja dan tidak adanya pelaporan lowongan perusahaan ke Dinas Sosial dan Tenaga Kerja Kabupaten Kampar. Upaya Penyelesian Terhadap Hambatan Pelaksanaan Penempatan Tenaga Kerja Tempatan Sesuai Peraturan Daerah Kabupaten Kampar Nomor 5 Tahun 2009 Tentang Penempatan Tenaga Kerja Pada PT. Flora Wahana Tirta adalah dengan Meningkatkan pelatihan kerja, melaksanakan job fair dan melakukan sosialisasi serta penyuluhan hukum.

Berbagai upaya dapat dilakukan agar Peraturan Daerah Kabupaten Kampar Nomor 5 Tahun 2009 Tentang Penempatan Tenaga Kerja dapat berjalan dengan maksimal, diantaranya perlu adanya sanksi bagi pengusaha atau perusahaan yang berdomisili di Kabupaten Kampar yang tidak melaksanakan apa saja yang telah diisyaratkan dalam Perda tersebut. Sanksi tersebut dapat berupa pencabutan izin bagi perusahaan yang tidak mau mempekerjakan tenaga kerja lokal di perusahaannya. Masyarakat lokal diharapkan mampu meningkatkan kualitas, menyiapkan diri dari segi pendidikan maupun pengalaman, dan kedepannya masyarakat telah siap dengan skill yang ditawarkan oleh pihak perusahaan. Dan terakhir Dinas tenaga kerja untuk melakukan sosialisasi secara rutin dan rinci kepada perusahaan yang ada di Kabupaten Kampar dan melakukan pengecekan secara rutin tenaga kerja yang ada diperusahaan tersebut.

\footnotetext{
${ }^{25}$ Wawancara dengan Bapak Razi Kani, S.Sos selaku Kepala Bidang Penempatan dan Pelatihan Produktifitas Tenaga Kerja Dinas Sosial dan Tenaga Kerja Kabupaten Kampar, pada hari Senin Tanggal 12 Februari 2018 bertempat di Dinas Sosial dan Tenaga Kerja Kabupaten Kampar
} 


\section{DAFTAR PUSTAKA}

Afrita, Indra, Hukum Ketenagakerjaan dan Penyelesaian Sengketa Hubungan Industrial di Indonesia,Yogyakarta: Absolute Media, 2015.

Ariani, Nevey Varida, "Penegakan Hukum Terhadap Tenaga Kerja Asing Ilegal Di Indonesia” Jurnal Penelitian Hukum De Jure 18, No. 1, Maret (2018).

Fuqoha, Perlindungan Hukum Terhadap Kesempatan Kerja Bagi Masayarakat Lokal Di Kota Cilegon, Jurnal Wawasan Yuridika 2, Nomor 2, September 2018.

Husainu, Muhammad Hasnan, Implementasi Kebijakan Peraturan Daerah Kabupaten Kampar No 5 Tahun 2009 Tentang Penempatan Tenaga Kerja Lokal (Studi Kasus Pt. Ramajaya Pramukti), Jurnal Online Mahasiswa Fakultas Ilmu Sosial dan Politik Universitas Riau 1, Nomor 2. Oktober (2014).

Husni, Lalu, Pengantar Hukum Ketenagakerjaan, Jakarta: PT.Raja Grafindo Persada, 2015.

Iroth, Delia Amanda, Aspek Hukum Pengembangan Sumber Daya Manusia (SDM ) Menurut Undang Undang No. 13 Tahun 2003 Tentang Ketenagakerjaan, Jurnal Lex Crimen 6, No. 2, Maret-April (2017)

Khakim, Abdul, Dasar-dasar Hukum Ketenagakerjaan Indonesia, Kalimanta Barat: PT Citra Aditya Bakti, 2009.

Kuncoro, Haryo, “Dimensikualitatif Keberhasilan Perluasan Kesempatan Kerja”, Jurnal Ekonomi dan Bisnis Indonesia 14, no. 1, (1999)

Sutedi, Andrian, Hukum Perburuhan, Jakarta: Sinar Grafika, 2011.

Warjiati, Sri. Hukum Ketenagakerjaan Keselamatan Kerja dan Perlindungan Upah Pekerja Wanita, Bandung: Tarsito,1998.

Wulandari, Gesang Sri, dan Nabitatus Sa'adah, Perlindungan Hukum Tenaga Kerja Indonesia Atas Kebijakan Pemerintah Terkait Penerimaan Tenaga Kerja Asing Di Indonesia, Kanun Jurnal Ilmu Hukum 21, No. 2, Agustus (2019).

Undang-Undang Dasar Negara Republik Indonesia Tahun 1945.

Undang-Undang Nomor 13 Tahun 2003 tentang Ketenagakerjaan.

Keputusan Presiden Nomor 4 Tahun 1980 tentang Wajib Lapor Lowongan Pekerjaan

Peraturan Daerah Kabupaten Kampar Nomor 5 Tahun 2009 tentang Penempatan Tenaga Kerja pada PT. Flora Wahana Tirta. 